\title{
LETTERS
}

\section{Respiratory syncytial virus and palivizumab prophylaxis in the COVID-19 era}

Across Canada, both influenza and respiratory syncytial virus (RSV) have been almost completely absent during the 2020/21 winter. ${ }^{1}$ Data from the Southern hemisphere showed the same phenomenon following the implementation of public health measures for coronavirus disease 2019 (COVID19). ${ }^{2}$ Despite the low incidence of RSV, programs across Canada have continued to promote the administration of palivizumab (PVZ) prophylaxis to eligible infants at a cost of about $\$ 1500$ per dose. Canadian taxpayers are currently on track to spend nearly $\$ 50$ million on a drug ${ }^{3}$ unlikely to have any benefit this winter.

In 2017, Mitchell and Peiris ${ }^{4}$ correctly pointed out that the social determinants of health need to be addressed when considering the effectiveness of PVZ prophylaxis for infants in the Artic with RSV. ${ }^{5}$ If they have not already done so, all Canadian PVZ programs need to immediately stop prophylaxis. Prophylaxis guidelines should be reviewed, with a switch to a flexible response to RSV activity. Palivizumab is an antibody, so unlike a vaccine, it becomes effective within hours of injection. Its administration can surely wait until there is significant risk of communityacquired RSV.

What will happen when COVID-19 rules are lifted? Will it become a societal norm to wash hands, wear a mask in crowded places, use hand sanitizer and avoid school or work for upper respiratory tract infections? We do not yet know. In Australia, there have been recent summer spikes in RSV activity, ${ }^{6}$ possibly related to a reduction in social distancing. Now that we have rediscovered a far more effective approach to infant hospital respiratory admissions, it would be foolish to assume that life will quickly return to normal. Prophylaxis programs for RSV will need to adjust to the new reality.

\section{Richard S. Taylor MB BS}

Neonatologist, Victoria General Hospital, Victoria, BC

- Cite as: CMAJ 2021 April 12;193:E523. doi: $10.1503 / \mathrm{cmaj} .78240$

\section{References}

1. Respiratory virus detections in Canada. Ottawa: Government of Canada; 2021. Available: www. canada.ca/en/public-health/services/surveillance/ respiratory-virus-detections-canada.html (accessed 2021 Jan. 29).

2. Yeoh DK, Foley A, Minney-Smith CA, et al. The impact of COVID-19 public health measures on detections of influenza and respiratory syncytial virus in children during the 2020 Australian winter. Clin Infect Dis 2020 Sep 24 [Epub ahead of print]. doi:10.1093/cid/ciaa1475.

3. Crowe K. Provinces spent $\$ 43 \mathrm{M}$ on preemie drug experts say can be made for a fraction of the cost. CBC News 2017 Apr. 6. Available: www.cbc. ca/news/health/rsv-drug-synagis-palivizumab -premature-infants-abbvie-provinces-health-care -1.4056823 (accessed 2021 Jan. 29)

4. Mitchell I, Peiris D. Reducing the burden of lower respiratory tract infections in infants in the Canadian Arctic. CMAJ 2017;189:E450-1.

5. Gilca R, Billard M-N, Zafack J, et al. Effectiveness of palivizumab immunoprophylaxis to prevent respiratory syncytial virus hospitalizations in healthy full-term <6-month-old infants from the circumpolar region of Nunavik, Quebec, Canada. Prev Med Rep 2020;20:101180.

6. Slezak M. Sharp rise in RSV infections among children has experts warning parents not to relax COVID-19 social distancing measures. ABC News 2020 Dec. 5. Available: www.abc.net.au/news/ 2020-12-06/sharp-rise-in-rsv-infections-among -children-covid-19-risk/12945930 (accessed 2021 Jan. 29)

Competing interests: Richard Taylor was chair of the British Columbia Respiratory Syncytial Virus Immunoprophylaxis Committee.

Content licence: This is an Open Access article distributed in accordance with the terms of the Creative Commons Attribution (CC BY-NC-ND 4.0) licence, which permits use, distribution and reproduction in any medium, provided that the original publication is properly cited, the use is noncommercial (i.e., research or educational use), and no modifications or adaptations are made. See: https://creativecommons.org/ licenses/by-nc-nd/4.0/ 